\title{
PENGARUH CORPORATE SOCIAL RESPONSIBILITY (CSR) DAN REPUTASI PERUSAHAAN TERHADAP NILAI PERUSAHAAN
}

\author{
Nur Afifah \\ irawan@umm.ac.id \\ Sri Wibawani Wahyuning Astuti \\ Dwi Irawan \\ Fakultas Ekonomi dan Bisnis Universitas Muhammadiyah Malang
}

\begin{abstract}
This study aims to provide empirical evidence about the effect of corporate social responsibility disclosure and corporate reputation on firm value. The population in this study were all manufacturing companies listed on the Indonesia Stock Exchange (IDX) in 2018. The sample in this study was 120 companies selected through purposive sampling. The results of data analysis show that CSR has a negative effect on firm value. But the company's reputation has a positive effect on the value of the company. This study also examines the impact of CSR disclosure on company value mediated by company reputation, the results show that company reputation does not mediate CSR disclosure on company value. This finding shows that CSR activities and company reputation are very important for the company's survival. A good relationship between the company and its stakeholders, especially the community in the form of Corporate Social Responsibility activities and a reputation that has been built by a company, will increase the value of a company which is reflected in the stock price which is formed by the demand and supply of the capital market that reflects the public's assessment of the company's performance.
\end{abstract}

Key words: CSR, corporate reputation, firm value

\begin{abstract}
ABSTRAK
Penelitian ini bertujuan untuk memberikan bukti empiris tentang pengaruh pengungkapan Corporate Social Responsibility dan Reputasi Perusahaan Terhadap Nilai Perusahaan. Populasi pada penelitian ini merupakan seluruh perusahaan manufaktur yang terdaftar pada Bursa Efek Indonesia (BEI) dalam tahun 2018. Sampel pada penelitian ini merupakan 120 perusahaan yang dipilih melalui purposive sampling. Hasil analisis data memperlihatkan bahwa CSR berpengaruh negatif terhdap Nilai perusahaan. Tetapi reputasi perusahaan berpengaruh positif terhadap nilai perusahaan. Pada penelitian ini juga menguji dampak pengungkapan CSR terhadap Nilai perusahaan yang di mediasi oleh reputasi perusahaan, hasilnya memperlihatkan bahwa reputasi perusahaan tidak memediasi pengungkapan CSR terhadap Nilai Perusahaan. Temuan ini memperlihatkan bahwa aktivitas CSR dan reputasi perusahaan sangat penting bagi kelangsungan hidup perusahaan. Hubungan yang baik antara perusahaan dengan para pemangku kepentingannya terutama masyarakat dalam bentuk kegiatan CSR dan reputasi yang telah dibangun oleh suatu perusahaan akan meningkatkan nilai suatu perusahaan yang tercermin dari harga saham yang dibentuk oleh permintaan dan penyediaan pasar modal yang mencerminkan penilaian publik terhadap kinerja perusahaan.
\end{abstract}

Kata kunci: CSR, nilai perusahaan, reputasi perusahaan

\section{PENDAHULUAN}

Dalam dunia usaha saat ini, laporan keuangan bukanlah satu-satunya hal yang menjadi tolak ukur dalam menilai kinerja sebuah perusahaan. Calon investor tidak hanya mengandalkan informasi keuangan saja dalam mengambil keputusan investasi. Epstein (1994) mengatakan bahwa pengambilan keputusan yang hanya dilihat dari sisisisi kinerja keuangannya saja, hal tersebut sudah tidak relevan lagi. Selain itu persaingan antar perusahaan saat ini juga semakin 
ketat, perusahaan tidak lagi hanya memikirkan tentang persaingan produk antara perusahaan satu dengan lainnya, namun perusahaan juga harus memperhatikan konsumen sehingga perusahaan dapat di nilai lebih dan memiliki keunggulan tersendiri baik dari produk maupun pelayanan oleh konsumen yang dapat meningkatkan nilai dari perusahaan tersebut.

Keller dan Richey (2006) dalam Jukić et al. (2018) menyatakan bahwa citra perusahaan akan mencerminkan nilai, perkataan, dan tindakan karyawan secara individu dan kolektif. Jika pengelolaan lingkungan adalah salah satu inti perusahaan, maka atribut seperti tanggung jawab dan kepedulian terhadap lingkungan akan tercermin dalam serangkaian ciri dari perusahaan tersebut yang dilihat oleh konsumen dan masyarakat umum. Setelah sebuah perusahaan memperkuat serangkaian ciri yang sesuai, konsisten dengan nilai-nilainya serta mendorong perilaku karyawan, sehingga perusahaan dapat mencapai kesuksesan yang berkelanjutan melawan para pesaingnya dan memiliki reputasi perusahaan yang baik kedepannya.

Secara keseluruhan, klaim bahwa reputasi perusahaan adalah bidang yang belum dipelajari tidak lagi valid. Literatur akademis yang mengeksplorasi tema dan berbagai isunya telah membuat kemajuan penting dalam dua dekade terakhir. Pengetahuan baru yang muncul dari penelitian teoritis dan empiris hingga saat ini menunjukkan bahwa reputasi merupakan aset penting yang mampu memberikan keunggulan kompetitif dan meningkatkan kinerja perusahaan. Oleh karena itu, ia memiliki nilai ekonomi yang signifikan (Geller, 2014). Reputasi perusahaan juga mengacu pada pola tingkah laku dan berbagai pendapat dari masyarakat secara natural berdasarkan realita yang menunjukkan indentitas dari sebuah perusahaan (Topalian, 1984). Reputasi sebagai penilaian kolektif pengamat dari sebuah perusahaan berdasarkan penilaian dari dampak keuangan, sosial, dan lingkungan yang dikaitkan dengan perusahaan dari waktu ke waktu. Reputasi mencerminkan persepsi kolektif dari kemampuan perusahaan untuk memberikan kualitas dan nilai, itu berfungsi sebagai "bingkai interpretatif di mana pemangku kepentingan dapat menilai kemungkinan bahwa perusahaan akan terus menunjukkan atribut nilai atau perilaku di masa depan" (Chalençon et al., 2017).

Corporate Social Responsibility (CSR) menjadi sorotan untuk menarik masyarakat sekitar dimana seseorang akan cenderung merasa bangga jika sebuah perusahaan juga peduli terhadap lingkungan sekitar, perusahaan di anggap juga memperhatikan dari segi aspek sosial dan lingkungannya. Yoon et al. (2006) menyatakan bahwa kegiatan CSR dapat digunakan untuk mengatasi kepedulian sosial pelanggan tentang suatu perusahaan, karena dapat menciptakan citra merek bagi perusahaan dan mengembangkan hubungan positif dengan pemangku kepentingan (stakeholders). Perusahaan tidak hanya beroperasi untuk kepentingan pemegang saham, tetapi juga untuk kepentingan Stakeholder dalam peraktik bisnis melalui penerapan tanggung jawab sosial perusahaan (CSR). Banyak Perusahaan terus berupaya untuk memastikan bahwa perusahaan tersebut telah beroperasi sesuai dengan aturan dan norma yang berlaku di masyarakat atau lingkungan dimana letak lokasi perusahaan berada, dan memastikan kegiatan operasional perusahaan di terima dengan sah (Deegan, 2002).

Penelitian sebelumnya, dilakukan oleh Wang (2012); dan Foote et al. (2010) yang percaya bahwa CSR dapat digunakan secara strategis untuk menumbuhkan nilai perusahaan namun, investasi ini juga dapat mengurangi nilai perusahaan dengan meningkatkan biaya dan mengalihkan fokus dari tujuan operasional. Sedangkan Becchetti et al. (2012) dalam penelitiannya menyatakan bahwa Temuan empiris dari beberapa studi mendukung sudut pandang ini, yang menunjukkan bahwa investasi dalam CSR membutuhkan sumber daya tambahan, yang meningkatkan biaya operasional dan mengurangi profitabilitas dan daya saing. 
Hal ini mencegah perusahaan mencapai tujuan mereka untuk memaksimalkan keuntungan. Statman et al. (2008) menemukan bahwa perusahaan yang mendapat peringkat lebih tinggi dalam CSR menunjukkan kinerja saham yang relatif lebih buruk.

Aktivitas CSR yang di terapkan oleh perusahaan yang tujuan utamanya adalah untuk meningkatkan layanan pelanggan tanpa mengabaikan pemangku kepentingan lainnya memiliki dampak positif terhadap kinerja suatu perusahaan yang di harapkan. CSR yang dilakukan perusahaan mampu menarik pelanggan sebagai pemangku kepentingan utama serta sebagai sumber kriteria pengambilan keputusan. Selain itu, CSR mampu membuat pelanggan sadar akan kontribusinya dalam kegiatan positif yang di lakukan oleh perusahaan yang membuat mereka memiliki rasa percaya terhadap perusahaan (Vélaz et al., 2007).

Pada penelitian Ali (2011) yang meneliti terkait hubungan antara CSR dan Reputasi perusahaan, menyatakan bahwa hasil dari penelitian tersebut reputasi perusahaan dipengaruhi secara kuat dan positif oleh tindakan corporate social responsibility (CSR) perusahaan. Hasil penelitian lainnya mengungkapkan bahwa terdapat hubungan yang mempengaruhi antara CSR dan reputasi perusahaan (Yadav et al., 2018) dan (Kelley et al., 2019). Pada penelitian Gray et al., (1995) dalam Farook et al. (2011) menyatakan bahwa tanggung jawab sosial perusahaan bermanfaat untuk meningkatkan reputasi perusahaan, menjaga citra dan strategi perusahaan.

Helm (2007) dalam Arikan et al. (2016) mengemukakan bahwa reputasi yang baik meningkatkan kepuasan investor dan loyalitas afektif terhadap suatu perusahaan, yang pada akhirnya mengarah pada perilaku loyalitas. Knight dan Pretty (1999) dalam penelitiannya juga menyimpulkan hal yang sama dengan menganalisis 15 krisis reputasi dan pengaruhnya terhadap kinerja keuangan yang berdampak terhadap nilai perusahaan. Roberts dan Dowling (2002) berfokus pada dampak reputasi perusahaan pada jalur kinerja keuangan masa depan, dengan menggunakan data perusahaan paling dikagumi dari Fortune sebagai ukuran reputasi 540 perusahaan dalam periode antara 1984 dan 1998.

Inovasi dan kontribusi terbesar mereka terletak pada analisis mereka tentang apakah reputasi yang baik memfasilitasi kinerja perusahaan yang lebih baik dari waktu ke waktu. Mereka juga mengontrol kinerja keuangan yang mendorong reputasi terbaik perusahaan dengan menguraikan reputasi menjadi reputasi keuangan terkait dengan kinerja keuangan dan reputasi terkait dengan faktor lain. Hasil mereka menunjukkan bahwa perusahaan yang memberikan hasil terbaik dari kegiatan perusahaan untuk mencapai tujuan memiliki peluang lebih besar untuk mempertahankan kinerja perusahaan dari waktu ke waktu jika mereka juga memiliki reputasi yang relatif baik.

Deephouse (2000) adalah orang pertama yang mengembangkan kritik terhadap perusahaan Fortune sebagai ukuran reputesi, dan mengembangkan ukuran baru dalam penelitian empirisnya yang disebut "reputasi media", evaluasi keseluruhan dari sebuah perusahaan yang disajikan di media. Ini diduga lebih kuat, karena tidak memiliki "bias keuangan", dan memperhitungkan kelompok pemangku kepentingan lainnya. Hasil analisis empirisnya menunjukkan bahwa reputasi perusahaan berpengaruh positif terhadap kinerja suatu nilai perusahaan. Penelitian yang di lakukan oleh Daromes (2020) menyatakan bahwa pengaruh reputasi perusahaan terhadap nilai perusahaan. Pengujian statistik secara positif memperkirakan bahwa reputasi perusahaan mempengaruhi nilai perusahaan, tetapi secara statistik tidak signifikan. Hal ini menunjukkan bahwa reputasi yang dibangun oleh perusahaan akan berdampak positif bagi stakeholders dalam bereaksi terhadap harga saham perusahaan, namun tidak terlalu berpengaruh terhadap nilai perusahaan yang diproksikan melalui harga saham yang ditawarkan. 
Makna yang dapat diambil dari pengujian di atas adalah bahwa reputasi yang dibangun perusahaan belum cukup berpengaruh terhadap pembentukan nilai perusahaan. Dengan kata lain, selain membangun reputasi, diperlukan mekanisme lain untuk mendukung pembentukan nilai perusahaan, misalnya tindakan nyata berupa perilaku sosial perusahaan, tindakan amal dan welas asih yang secara konsisten dan berkelanjutan dialami oleh masyarakat dan stakeholders pada umumnya

Ghahroud et al. (2020) mengkaji hubungan antara CSR dengan kinerja perusahaan dan reputasi perusahaan. Hasil penelitian yang menunjukkan bahwa terdapat hubungan positif yang signifikan antara pengungkapan CSR dengan kedua indikator tersebut. Hasil ini memverifikasi hipotesis yang juga sejalan dengan kerangka teori yang memprediksi bahwa ada hubungan positif antara kinerja sosial perusahaan dan kinerja keuangan (pendapatan perusahaan) serta reputasi perusahaan, sehingga dapat disimpulkan bahwa semakin tinggi tingkat CSR maka semakin baik pula reputasi perusahaan, pendapatan dan profitabilitas perusahaan. Kegiatan CSR berdampak positif terhadap brand perusahaan dan akhirnya berdampak positif terhadap kinerja keuangan seperti pendapatan, sehingga perusahaan harus memasukkan CSR ke dalam kebijakannya sehingga dapat membantu perusahaan dalam mencapai tujuan perusahaan sehingga dapat meningkatkan nilai perusahaan.

Penelitian ini dilakukan untuk mengungkapkan seberapa besar peran pengungkapan Corporate Social Responsibility dan Reputasi perusahaan terhadap nilai perusahaan, dari uraian di atas terdapat beberapa ketidak konsistenan hasil penelitian sebelumnya, sehingga mendorong peneliti untuk melakukan penelitian ulang serta dapat memperkuat penilitian sebelumnya, Berdasarkan uraian diatas, rumusan masalah dalam penelitian ini antara lain: 1) Bagaimana Pengaruh Corporate Social Responsibility (CSR) terhadap Nilai Perusa- haan?, 2) Bagaimana Pengaruh Corporate Social Responsibility (CSR) terhadap Reputasi Perusahaan?, 3) Bagaimana Pengaruh Reputasi Perusahaan terhadap Nilai Perusahaan?

Tujuan penelitian ini adalah untuk mengetahui seberapa besar pengaruh pengungkapan CSR terhadap peningkatan nilai perusahaan, pengaruh pengungkapan CSR terhadap reputasi perusahaan, serta melihat pengaruh pengungkapan reputasi perusaan terhadap nilai perusahaan. Dalam penelitian ini masih belum banyak peneliti yang menghubungkan CSR, reputasi perusahaan dan Nilai perusahaan. Perbedaan penelitian ini dengan penelitian sebelumnya juga melihat apakah pengaruh CSR terhadap nilai perusahaan dapat di mediasi oleh reputasi perusahaan.

\section{TINJAUAN TEORETIS \\ Stakeholder Teori}

Kompleksitas tantangan bisnis saat ini menyebabkan banyak akademisi dan praktisi mencoba menggunakan konsep dan model untuk membantu memahami tantangan tersebut, salah satunya adalah Stakeholders Theoy (teori pemangku kepentingan). Menurut Ghozali (2020) teori ini di perkenalkan pertama kali oleh Freeman (1994), yang membantu mengatasi 3 masalah bisnis yang saling berhubungan:

1. Masalah penciptaan Nilai dan Perdagangan: Dalam konteks bisnis global yang berubah dengan cepat.

2. Masalah Etika Kapitalisme:

3. Masalah Pola Pikir Manajerial: terkait dengan pola pikir kedua masalah di atas.

Teori pemangku kepentingan menyatakan bahwa jika kita mengambil hubungan antara perusahaan, kelompok, dan individu sebagai unit analisis, maka kita akan memiliki kesempatan untuk menyelesaikan ketiga masalah tersebut. Dari perspektif pemangku kepentingan, bisnis dapat didefinisikan sebagai seperangkat hubungan kelompok yang memiliki kepentingan dalam kegiatan yang membentuk bisnis, di mana tim dan manajer bekerja sama untuk menciptakan nilai sebanyak mungkin bagi 
pemangku kepentingan untuk mengelola dan bertukar nilai, sehingga kebutuhan pemangku kepentingan dapat dipenuhi tanpa kegagalan etis.

Teori pemangku kepentingan berpandangan bahwa perusahaan tidak hanya beroperasi untuk keuntungannya sendiri, tetapi juga menguntungkan stakeholder (pemegang saham, kreditur, konsumen, pemasok, pemerintah, masyarakat, analis, dan pihak lain) karena kelangsungan hidup perusahaan sangat dipengaruhi oleh dukungan dari pemangku kepentingan, dan karena itu upaya besar perusahaan untuk beradaptasi. Pengungkapan di jejaring sosial dianggap sebagai bagian dari dialog antara perusahaan dan pemangku kepentingannya.

Friedman (1984) menyimpulkan bahwa tujuan sebenarnya dari perusahaan adalah untuk memenuhi kebutuhan para pemangku kepentingannya. Semakin kuat pemang$\mathrm{ku}$ kepentingan, semakin banyak perusahaan akan mencoba beradaptasi dengan kebutuhan pemangku kepentingan (Mahrani dan Soewarno, 2018). Eksistensi suatu bisnis tergantung pada dukungan dari para pemangku kepentingannya dan dukungan ini harus dicari Gray et al., (1995) dalam Farook et al. (2011). Stakeholder theory penting dalam penelitian ini karena teori tersebut berkaitan dengan pemangku kepentingan perusahaan yang akan mempengaruhi dan dipengaruhi oleh aktivitas bisnis, seperti pertanggungjawaban manajemen kepada pemangku kepentingan dalam bentuk kegiatan CSR dan aktivitas keuangan perusahaan.

\section{Tanggung Jawab Sosial (CSR)}

Palmer (2012) mendefinisikan CSR sebagai "tindakan yang mendorong kegiatan sosial, di luar kepentingan perusahaan dan apa yang disyaratkan oleh hukum. Untuk memahami definisi ini membutuhkan pengakuan bahwa kebijakan CSR adalah tindakan yang melampaui kepatuhan uhkum menjadi hal yang positif berdampak pada masyarakat (komunitas, lingkungan, karyawan, dan lain-lain). program tanggung ja- wab sosial perusahaan termasuk tindakan untuk memperbaiki lingkungan, masyarakat, dan kehidupan semua pemangku kepentingan dari sebuah organisasi. Lanis dan Richardson (2012) berpendapat bahwa CSR merupakan faktor kunci kesuksesan dan kelangsungan hidup perusahaan. Penerapan CSR dapat menjadikan perusahaan memiliki citra yang baik di mata masyarakat sehingga dapat membangun hubungan dan menciptakan reputasi yang baik di pasar saham.

Menurut Aras dan Crother, 2008 dalam (Jackson dan Jackson, 2017: 105-118) mengatakan bahwa ada 3 prinsip utama CSR, yaitu: 1. Sustainability

Prinsip ini berkaitan dengan dampak sebuah tindakan yang diambil pada masa sekarang dapat memiliki beberapa kemungkinan ketersediaan di sumber daya di masa depan. Apakah cukup atau tidak sumber daya tersebut di masa depan. Hal ini menjadi perhatian penting bagi sumber daya yang mempunyai jumlah terbatas.

2. Akuntabilitas

Akuntabilitas berkaitan dengan pengakuan perusahaan dalam melakukan tindakan yang mempengaruhi lingkungan sekitar perusahaan dan karena pengakuan tersebut perusahaan berasumsi untuk bertanggung jawab pada tindakan yang dilakukan. Prinsip ini berdampak pada perhitungan dari tindakan yang akan diambil perusahaan baik internal organisasi maupun eksternal.

3. Transparansi

Transparansi merupakan prinsip dasar mekanisme pelaporan perusahaan, pelaporan yang diungkapkan, diharapkan setiap kegiatan yang dilakukan dipastikan akan dilaporkan secara fakta yang ada dan tidak disembunyikan dalam laporan tersebut.

Banyak perusahaan yang berkomitmen terhadap CSR, karena perusahaan yang terlibat dalam kegiatan CSR dapat menjaga kualitas hubungan dengan investor sehingga perusahaan akan berusaha untuk tidak 
mempraktikkan manajemen laba. Gras-Gil et al. (2016) penekanan terhadap transparansi akan mendorong manajemen untuk menyajikan laporan yang menggambarkan keadaan yang sebenarnya terhadap kondisi perusahaan.

\section{Tabel 1 \\ 32 Indikator CSR}

\begin{tabular}{|c|c|}
\hline Lingkungan & Sosial \\
\hline $\begin{array}{l}\text { Daur Ulang } \\
\text { (Recycled) } \\
\text { Konsumsi Energi } \\
\text { Keanekaragaman } \\
\text { Hayati } \\
\text { Emisi } \\
\text { Limbah } \\
\text { Sampah } \\
\text { Tumpahan (Spills) } \\
\text { Dampak } \\
\text { lingkungan }\end{array}$ & $\begin{array}{l}\text { Pekerjaan } \\
\text { (employment) } \\
\text { Turnover karyawan } \\
\text { Musyawarah } \\
\text { Kesepakatan } \\
\text { Bersama } \\
\text { Kesehatan Kerja } \\
\text { Keselamatan Kerja } \\
\text { Pelatihan } \\
\text { Keragaman } \\
\text { Kesetaraan } \\
\text { Hak Asasi } \\
\text { Diskriminasi } \\
\text { Kebebasan } \\
\text { Berkumpul } \\
\text { Pekerja Anak } \\
\text { Kerja Paksa } \\
\text { Kerja Wajib } \\
\text { Komunitas } \\
\text { Korupsi } \\
\text { Kebijakan Publik } \\
\text { Kepatutan } \\
\text { Denda } \\
\text { Sanksi } \\
\text { Tanggungjawab } \\
\text { Produk } \\
\text { Kesehatan } \\
\text { Pelanggan } \\
\text { Keselamatan } \\
\text { Pelanggan }\end{array}$ \\
\hline
\end{tabular}

Sumber : Gamerschlag et al. (2011)

Yaldo et al. (2014) menyatakan bahwa kerangka pelaporan keberlanjutan yang komprehensif yang paling banyak digunakan di seluruh dunia telah dibuat dan ditingkatkan oleh global reporting initiative (GRI). Laporan keberlanjutan adalah laporan yang dikeluarkan oleh organisasi (swasta, publik, atau nirlaba) yang melaporkan dampak ekonomi, lingkungan, dan sosial serta kinerja aktivitas, produk, dan layanan mereka. Pelaporan tersebut menggunakan pendekatan Triple Bottom Line (TBL) profit", "people", dan "planet, sesuai dengan tujuan awal perusahaan yaitu profit perusahaan juga harus memperhatikan kesejahteraan masyarakat sekitar ikut serta dalam menjaga kelestarian lingkugan.

Penelitian ini menggunakan 32 indikator yang dikembangkan oleh Gamerschlag et al. (2011), dimana indikatornya berasal dari kata kunci kerangka Global Reporting Initiative (GRI). Indikator-indikator tersebut memiliki validitas hasil yang baik dan dapat dianggap mencerminkan makna sebenarnya dari tanggung jawab sosial perusahaan. Ke32 indikator tersebut ditunjukkan pada Tabel 1.

\section{Reputasi Perusahaan}

Reputasi perusahaan merupakan keseluruhan dari estimasi perusahaan yang dipegang oleh konstitusinya. Reputasi perusahaan memberikan gambaran hasil dari baik buruknya perusahaan serta hasil keefektifan atau tindakan emosional, melihat sisi kuat lemahnya perusahaan terhadap pandangan dari perspektif karyawan, investor, konsumen, serta masyarakat publik (Fombrun et al., 2015). Pengolahan informasi yang baik yang di lakukan oleh perusahaan berdampak terhadap reputasi perusahaan yang tergambar secara jelas dan keseluruhan sehingga dapat memberikan kesan tersendiri dari golongan tertentu terhadap perusahaan Alvesson (1990). Ide atau gagasan perusahaan yang dapat di terima oleh public dapat menjadikan acuan bagaimana perusahaan itu di kenal dan bagaimana perusahaan itu di pandang oleh masyarakat public terkait dengan kondisi perusahaan, sehingga memberikan citra yang positif terhadap perusahaan tersebut (Wicaksono, 2020).

Teori studi organisasi, seperti teori kelembagaan dan teori pemangku kepentingan memandang reputasi sebagai fokus 
pada proses mendapatkan legitimasi dengan aktor di lingkungan kelembagaan. Rao (1994) dalam Petkova (2016) mengamati bahwa perusahaan harus mendapatkan legitimasi dan dukungan budaya di lingkungan kelembagaannya untuk membangun reputasi. Teori pemangku kepentingan menunjukkan bahwa reputasi yang baik dengan pemangku kepentingan utama diperlukan untuk menjamin dukungan mereka, sehingga menjadi penting untuk kesuksesan jangka panjang Freeman dan McVea (2001) dalam (Roszkowska-Menkes, 2018).

Geller (2014) menyatakan bahwa reputasi dikembangkan melalui tiga proses sosial: (1) pembentukan, (2) refraksi, dan (3) penilaian. Shaping adalah proses di mana perusahaan melakukan upaya strategis untuk membangun reputasinya. Dalam pengertian ini, ada empat hubungan utama (1) hubungan pelanggan, (2) hubungan investor, (3) hubungan karyawan, (4) hubungan masyarakat dan dua hubungan tambahan yaitu (5) hubungan pemerintah, dan (6) publik atau hubungan media. Semua relasi ini dimaksudkan untuk memproyeksikan gagasan tentang organisasi. Jika kita mengadopsi definisi konstruksi Walker (2010), hubungan ini bermaksud untuk memperkuat atau mengubah identitas melalui hubungan karyawan dan juga untuk mengubah citra persepsi yang diinginkan oleh orang lain menjadi reputasi persepsi yang nyata.

\section{Nilai Perusahaan}

Menurut Bidhari et al. (2013) nilai perusahaan didefinisikan sebagai nilai pasar.
Nilai perusahaan dapat memberikan kekayaan untuk pemegang saham secara maksimal jika harga saham meningkat. Semakin tinggi harga saham, semakin tinggi kekayaan pemegang saham. Jika nilai saham perusahaan tinggi dapat di simpulkan bahwa nilai perusahaan tersebut baik, Karena mereka melihat harga saham dan mengatakan bahwa nilai perusahaan itu bagus. Tujuan utama suatu perusahaan untuk meningkatkan nilainya dapat dicapai dengan meningkatkan tingkat kemakmuran pemilik atau pemegang sahamnya.

Memaksimalkan harga saham dapat dilihat dengan melihat kinerja suatu perusahaan dalam jangka panjang. Jika manajer ingin memaksimalkan harga saham, mereka perlu mengetahui bagaimana harga itu ditentukan. Karena harga saham perusahaan akan menjadi acuan informasi bagi investor untuk memutuskan apakah akan membeli saham perusahaan tersebut apakah akan menanamkan modalnya pada perusahaan tersebut, karena aset investor adalah sejumlah Saham yang dimilikinya dikalikan dengan harga sahamnya, investor tidak boleh lalai dalam mengidentifikasi atau memilih perusahaan apa yang akan di beli.

\section{Kerangka Pemikiran Penelitian}

Berdasarkan dari penjelasan latar belakang dan tinjauan teoretis yang telah dijelaskan diatas, maka dapat digambarkan kerangka pemikiran dari penelitian ini terdapat dalam Gambar 1.

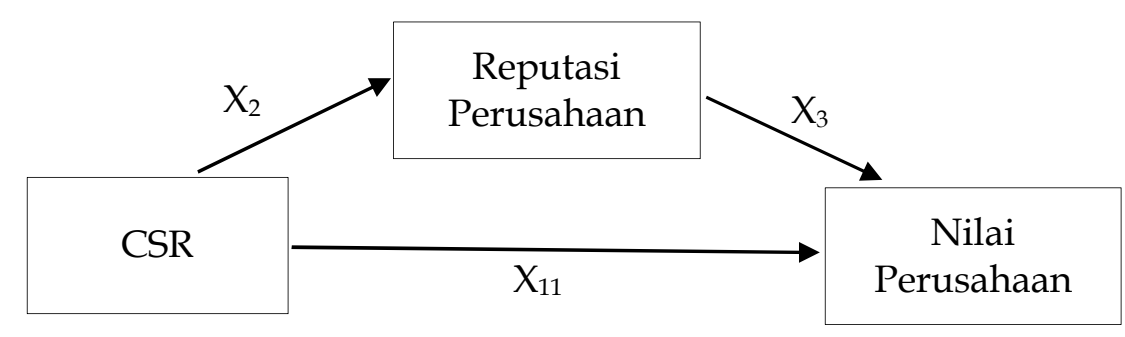

Gambar 1

Kerangka Pemikiran Penelitian

Sumber: Jo dan Harjoto (2011); Gilbert et al. (2005); Rose dan Thomsen (2004). 


\section{Pengaruh Corporate Social Responsibility Terhadap Nilai Perusahaan}

Kinerja sosial yang kuat mengarah pada hasil keuangan yang lebih kuat. Dengan meningkatkan reputasi perusahaan, perusahaan dapat mengurangi risiko komersial dan mendapatkan lebih banyak dukungan dari regulator. Ini akan membawa lebih banyak investasi untuk memenuhi harapan berbagai pemangku kepentingan dan meningkatkan nilai perusahaan. Jo dan Harjoto (2011) juga menemukan bahwa CSR dapat secara efektif meningkatkan nilai pasar perusahaan.

Karaye et al. (2014) menyatakan bahwa melaui CSR perusahaan dapat mengidentifikasi, bertindak, dan mengambil keuntungan untuk meningkatkan hubungan dengan stakeholder. Menurut Parket dan Eilbirt (1975) manfaat yang diperoleh dari pemenuhan CSR melebihi biaya, meningkatkan nilai perusahaan. Dengan melindungi kesejahteraan karyawan melalui CSR, dapat diwujudkan untuk meningkatkan produktivitas, meningkatkan citra perusahaan, membangun kepercayaan publik, serta meningkatkan citra merek dan daya saing. Berdasarkan dari uraian tersebut hipotesis penelitian ini adalah:

$\mathrm{H}_{1}$ : Pengungkapan Corporate Social Responsibility (CSR) berpengaruh terhadap Nilai Perusahaan.

\section{Pengaruh Corporate Social Responsibility Terhadap Reputasi Perusahaan}

Beberapa kelompok atau masyarakat memiliki pandangan etis tentang reputasi, mereka melihatnya sebagai ekspresi ideologi dan nilai perusahaan. Menurut pandangan ini, penting bahwa strategi reputasi mencerminkan apa yang diharapkan konstituen dari perusahaan, dan bahwa pemangku kepentingan ini dilibatkan dalam proses pembangunan strategi Gilbert (2005) Dalam hal ini, strategi perusahaan harus menjadi pernyataan prinsip etika tentang manusia yang bergaul untuk mengejar ambisi yang layak. Pendekatan ini sangat menarik ketika menyelidiki hubungan antara tanggung jawab sosial perusahaan dan reputasi peru- sahaan. Berdasarkan uraian tersebut maka hipotesis penelitian ini adalah:

$\mathrm{H}_{2}$ : Pengungkapan Corporate Social Responsibility (CSR) berpengaruh terhadap Reputasi Perusahaan.

\section{Pengaruh Reputasi Perusahaan Terhadap Nilai Perusahaan}

Para peneliti telah menekankan pentingnya menjaga reputasi perusahaan, yang didefinisikan sebagai "representasi kognitif dari tindakan dan hasil perusahaan yang mengkristalkan kemampuan perusahaan untuk memberikan hasil yang berharga kepada pemangku kepentingannya (Fombrun et al., 2015).

Devine dan Halpern (2001) dalam Chalençon et al. (2017) menyatakan bahwa reputasi perusahaan dapat di jadikan gambaran yang ditangkap oleh publik tentang suatu entitas, tentang bagaimana kualitas produk, layanan, karakteristik pekerjaan, strategi, dan prospek mereka dibandingkan dengan pesaing mereka. Beberapa penelitian termasuk Dierickx dan Cool (1989); Weigelt dan Camerer (1988) yang menjelaskan bahwa reputasi perusahaan yang baik memiliki nilai strategis bagi pemiliknya. Efek sampingnya adalah perusahaan akan memiliki daya saing yang lebih unggul dibandingkan kompetitornya dan juga dapat memperoleh keuntungan yang lebih tinggi. Argumen di atas didukung oleh pernyataan Rose dan Thomsen (2004) menyatakan bahwa reputasi perusahaan yang baik memiliki karakteristik aset tidak berwujud dan dapat memberikan keunggulan bersaing bagi perusahaan yang pada akhirnya menghasilkan abnormal return. Hal senada dikemukakan Wei et al. (2017) yang menjelaskan bahwa perusahaan dengan reputasi yang baik akan cenderung mem-pertahankan kinerjanya bahkan dalam situasi krisis. Pada jalur penalaran di atas bukti empiris yang telah disampaikan dapat dijadikan untuk menarik kesimpulan bahwa reputasi yang baik sangat penting karena berpotensi menciptakan nilai suatu perusahaan yang pada akhirnya akan meningkatkan nilai perusahaan. Berdasarkan uraian 
tersebut maka hipotesis penelitian ini adalah:

$\mathrm{H}_{3}$ : Reputasi Perusahaan berpengaruh terhadap Nilai Perusahaan.

\section{METODE PENELITIAN \\ Jenis Penelitian}

Jenis penelitian ini adalah jenis penelitian Asosiatif yang bertujuan untuk menganalisis hubungan antara suatu variabel dengan variabel yang lain, dapat berupa hubungan biasa atau hubungan sebab akibat (Ulum dan Juanda, 2018). Penelitian ini juga merupakan penelitian eksplanatori dimana pada penelitian ini juga melihat apakah hasil uji statistic memperkuat atau memperkuat teori berdasarkan hipotesis yang dibangun dalam penelitian.

\section{Populasi dan Sampel}

Populasi dalam penelitian ini adalah perusahaan manufaktur yang terdaftar di BEI tahun 2018. Sampel penelitian diambil dengan menggunakan metode purposive sampling, dengan kriteria sebagai berikut:

1. Perusahaan manufaktur di Indonesia yang telah terdaftar di Bursa Efek Indonesia (BEI) tahun 2018.

2. Mengungkapkan informasi sosial dan informasi lainnya yang dibutuhkan di tahun 2018.

3. Memiliki data yang lengkap terkait dengan variabel-variabel yang digunakan dalam penelitian.

\section{Teknik Perolehan Data}

Teknik perolehan data pada penelitian ini menggunakan data sekunder yaitu dokumentasi. Dokumentasi tersendiri merupakan teknik untuk memperoleh data yang sudah jadi dan sudah diolah orang lain. Peneliti cukup memanfaatkan data tersebut Ulum dan Juanda (2018), yaitu berupa laporan keuangan perusahaan manufaktur yang terdaftar di BEI. Definisi Operasional dan Pengukuran
Variabel

Tanggung Jawab Sosial

Corporate Social Responsibility (CSR). CSR merupakan tantangan yang harus dihadapi perusahaan modern. Perusahaan, di kondisi hypercompetition bersaing untuk mendapatkan klien yang ekspektasinya meningkat secara dinamis. Melihat dari segi produk yang di hasilkan perusahaan saja tidaklah cukup bagi konsumen, tetapi Tanggung Jawab Sosial Perusahaan seorang produsen juga sama pentingnya. Oleh karena itu, Corporate Social Responsibility saat ini dipersepsikan sebagai investasi yang Meningkatkan kinerja perusahaan (KadłubeNa, 2015).

Di Indonesia sendiri masih banyak perusahaan yang tidak melaporkan kinerja sosial, ekonomi dan lingkungannya, sehingga penelitian ini pun terbatas terkait dengan data-data yang dapat di peroleh dari laporan tahunan perusahaan, dengan hal itu agar tidak terjadi kesenjangan antar perusahaan satu dengan perusahan lainnya, Siregar (2007). Anggraeni dan Djakman (2018) menyatakan adanya peningkatan tren pengungkapan yang mengindikasikan adanya langkah perbaikan terhadap kualitas informasi pengungkapan tanggung jawab sosial perusahaan.

Indeks pengungkapan CSR berdasarkan 32 kata kunci pada tabel 1 di atas, di rumuskan menggunakan Rumus perhitungan (Corporate Social Responsibility Disclosure Index) CSRDI adalah sebagai berikut : $\mathrm{CSR}=\frac{\text { Nilai Total "1" }}{\text { Jumlah Item } 32 \text { kata kunci GRI }}$

\section{Reputasi Perusahaan}

Reputasi perusahaan adalah ukuran evaluasi pemangku kepentingan tentang seberapa baik kinerja perusahaan, apakah perusahaan memenuhi harapan pemangku kepentingan, dan seberapa baik kinerja perusahaan secara keseluruhan cocok dengan lingkungan sosial dan politik. digambarkan sebagai kombinasi jangka panjang (Logsdon dan Wood, 2002). 
Akibatnya, reputasi perusahaan telah didefinisikan sebagai jenis umpan balik tertentu yang diterima oleh organisasi dari para pemangku kepentingannya, mengenai kredibilitas klaim identitas organisas, sedangkan reputasi perusahaan berasal dari persepsi atau pandangan dari semua pemangku kepentingan. Greyser (1999) dalam (Boddy, 2012) mengidentifikasi salah satu dampak reputasi perusahaan terhadap pelanggannya adalah dampak luasnya pada persepsi pelanggan tentang nilai finansial dan loyalitas perusahaan.

Dalam penelitian ini, kami menggunakan temuan yang dipublikasikan dalam artikel "100 Outstanding Growth Companies Ranking 2018" Media Bisnis Indonesia sebagai proksi reputasi perusahaan. Dari hasil survei ini, 100 dari 566 perusahaan memiliki kinerja terbaik mengingat lika-liku kondisi ekonomi yang melanda Indonesia akhirakhir ini. Reputasi perusahaan diukur dengan variabel dummy, 1 poin jika sampel termasuk dalam 100 perusahaan yang sangat baik, 0 poin jika tidak termasuk dalam 100 perusahaan.

\section{Nilai Perusahaan}

Variabel terikat dalam penelitian ini adalah nilai perusahaan. Nilai perusahaan adalah penilaian atas perusahaan yang diukur dengan nilai saham yang diterbitkan di pasar. Harga saham didasarkan pada proyeksi arus kas untuk tahun ini serta untuk beberapa tahun ke depan (Brigham dan Houston, 2013).

Tobin $Q$ yang digunakan pada penelitian ini dihitung dengan rasio $Q$ yang telah di modifikasi oleh Lee et al. (2019).

TOBINS $\mathrm{Q}=\frac{M V E+D}{T A}$

Keterangan:

1. $\mathrm{MVE}=$ Closing price end of the years $\mathrm{x}$ number of stock or share

2. $\mathrm{D}=$ Total liabilitas

3. $\mathrm{TA}=$ Total Aset

\section{Teknik Analisis Data}

Dalam penelitian ini, data diolah dan dianalisis menggunakan alat statistik yaitu Stata15 dengan mengikuti langkah-langkah analisis berikut:

1. Melakukan analisis statistika deskriptif. Analisis statistik deskriptif dilakukan untuk mendapatkan gambaran tentang data yang diolah dengan membuat tabel statistik yang digunakan dalam penelitian ini untuk mendapatkan mean, median, modus, dan standar deviasi dari masingmasing variabel dalam data yang diolah.

2. Uji Multikolineritas dilakukan untuk memeriksa apakah model regresi menemukan korelasi antara variabel independen. Jika tidak terdapat korelasi antar variabel bebas, maka model regresi tersebut dapat dikatakan baik. Untuk mengetahui adanya multikolinearitas, nilai 1/VIF dan Variance Inflation Factor (VIF) dapat dipertimbangkan. Nilai ambang batas yang umum digunakan untuk menunjukkan adanya multikolinearitas adalah VIF $<0,10$ atau sama dengan nilai VIF dan nilai $1 / \mathrm{VIF}>0.1$.

3. Uji Heteroskedastisitas digunakan untuk memeriksa apakah ada ketidaksamaan varians pada pengamatan lain dengan residual satu pengamatan dalam model regresi. Disebut homoskedastisitas, yang memiliki varians dan residual dari satu pengamatan ke pengamatan lainnya, dan disebut heteroskedastisitas, yang berbeda. Metode pendeteksian ada tidaknya heterokedastisitas dapat disimpulkan bahwa tidak ada homogenitas bila hasil prob>Chi2 lebih besar dari 0,05 dengan melakukan uji heterokedastisitas, dan Manyimpulkan bahwa lulus uji heterokedastisitas.

4. Uji Hipotesis. Pada penelitian ini menggunakan uji regresi berganda, model regresi berganda melibatkan lebih dari satu variabel bebas, dilakukan uji regresi berganda untuk mengetahui pengaruh dan kemampuan variabel dalam menjelaskan variabel independent dengan nilai 
di bawah 0,05 dapat dikatakan hubungan kedua variabel berpengaruh.

5. Uji Mediasi. Penelitian ini menguji mediasi menggunakan uji Sobel. Uji Sobel secara konservatif menguji reduksi data dengan membagi efek moderator dengan kesalahan standarnya dan membandingkannya dengan distribusi normal standar untuk menguji signifikansinya. Metode estimasi tersebut dapat digunakan untuk model yang lebih kompleks (Irawan et al., 2019).

\section{ANALISIS DAN PEMBAHASAN \\ Distribusi Sampel Penelitian}

Berdasarkan kriteria pusposive sampling di atas, maka diperoloeh sampel penelitian ini yang digambarkan pada tabel 2 .

\section{Deskriptif Variabel Penelitian}

Deskriptif variabel penelitian berdasarkan perolehan data dari 120 perusahaan manufaktur 2018 yang ada di Bursa Efek Indonesia ditunjukkan pada Tabel 3, yang menunjukkan bahwa nilai rata-rata tertinggi berada pada variabel nilai perusahaan yang mana diukur menggunakan rumus dari Tobins Q yang di modifikasi oleh Lee et al. (2019) sebesar 4,53, sedangkan rata-rata pengungkapan CSR di Indonesia berdasarkan 32 indikator yang di kembangkan oleh (Gamerschlag et al., 2011) adalah sebesar 0,28 .

Rata rata variabel reputasi perusahaan yaitu 0,16 dengan mode 0 , dimana hasil dari pengukurannya dengan menggunakan variabel dummy dengan melihat daftar 100 perusahaan yang bereputasi baik menurut hasil riset yang dipublish di artikel pada Media Bisnis Indonesia yang berjudul "100 excellent growth company ranks 2018" sebagai proxy variabel reputasi perusahaan.

\section{Uji Multikolneritas}

Berdasarkan Tabel 4, hasil Uji Multikolineritas dalam penelitian ini VIF adalah 1,08 menunjukkan hasil tersebut lebih kecil dari 10 dan 1/VIF adalah 0,93 lebih besar dari 0,1 yang menunjukkan tidak adanya hubungan antar variabel menyimpulkan bahwa bebas dari gejala multikol.

Tabel 2

Distribusi Sampel

\begin{tabular}{clcc}
\hline No & \multicolumn{1}{c}{ Kriteria } & $\begin{array}{c}\text { Jumlah } \\
\text { Perusahaan }\end{array}$ \\
\hline \hline 1. & $\begin{array}{l}\text { Perusahaan-perusahaan manufaktur di Indonesia } \\
\text { terdaftar di Bursa Efek Indonesia (BEI) tahun 2018 }\end{array}$ & yang telah \\
$\begin{array}{l}\text { 2. } \\
\text { Tidak mengungkapkan informasi CSR dan informasi lainnya yang } \\
\text { dibutuhkan selama tahun 2018 } \\
\text { Total Perusahaan Sampel Penelitian }\end{array}$ & $(56)$ \\
\hline Sumber: Data Sekunder yang diolah & $\mathbf{1 2 0}$ \\
\hline
\end{tabular}

Tabel 3

Statistik Deskriptif Variabel Penelitian

\begin{tabular}{ccccc}
\hline Variabel & Mean & Median & Mode & Standart Deviation \\
\hline CSR & 0.28 & 0.25 & 0.22 & 0.16 \\
Reputasi Perusahaan & 0.16 & 0 & 0 & 0.37 \\
Nilai Perusahaan & 4.53 & 2.20 & & 5.53 \\
\hline
\end{tabular}

Sumber: Data Sekunder yang diolah 
Tabel 4

Uji Multikolineritas

\begin{tabular}{lcl}
\hline \multicolumn{1}{c}{ Variabel } & VIF & 1/VIF \\
\hline \hline CSR & 1.08 & 0.93 \\
Reputasi Perusahaan & 1.08 & 0.93 \\
Mean VIF & 1.08 & \\
\hline
\end{tabular}

Sumber: Data Sekunder yang diolah

\section{Uji Heteroskedastisitas}

Dalam uji Heteroskedastisitas hasil uji dalam penelitian ini chi2 (1) = 1,02 dan Prob $>$ chi2 $=0,6116$, menunjukkan bahwa tidak terjadi homogenitas.

\section{Uji Hipotesis}

Pengujian Hipotesis menggunakan Program Stata 15 dengan melihat nilai $p$ value dan nilai $t$ pada masing-masing hipotesis, yang mana dapat di lihat pada Tabel 5 .

\section{Tabel 5}

\section{Uji Regresi Berganda}

\begin{tabular}{lccc}
\hline \multicolumn{1}{c}{ Variabel } & $\mathbf{t}$ & $\mathbf{p}>|\mathbf{t}|$ & Kesimpulan \\
\hline \hline CSR $\rightarrow$ Nilai & - & 0.050 & Ditolak \\
$\begin{array}{l}\text { Perusahaan } \\
\text { CSR } \rightarrow\end{array}$ & 1.98 & & \\
$\begin{array}{l}\text { Reputasi } \\
\text { Perusahaan }\end{array}$ & 3.00 & 0.003 & Diterima \\
$\begin{array}{l}\text { Reputasi } \\
\text { Perusahaan } \\
\rightarrow \text { Nilai }\end{array}$ & 2.53 & 0.013 & Diterima \\
$\begin{array}{l}\text { Perusahaan } \\
\text { Sumber: Data Sekunder yang diolah }\end{array}$ & & \\
\hline
\end{tabular}

Tabel 6

R-Square

\begin{tabular}{lc}
\hline \multicolumn{1}{c}{ Variabel } & R-Square \\
\hline \hline Reputasi Perusahaan & 0.0707 \\
Nilai Perusahaan & 0.0659 \\
\hline
\end{tabular}

Sumber: Data Sekunder yang diolah

Tabel 6 menunjukkan R-Square variabel independent. Nilai R-Square variabel reputasi perusahaan sebesar 0,0707 artinya variabel CSR mampu menjelaskan variabel reputasi perusahaan sebesar $7 \%$, sedangkan vari- abel berikutnya Nilai perusahaan dengan RSquare sebesar 0,0659 yang menandakan bahwa CSR dapat menjelaskan variabel nilai perusahaan sebesar $6,5 \%$.

Selain itu peneliti juga melakukan sobel test untuk menguji variabel mediasi terkait dengan hubungan pada variabel penelitian. Dapat di lihat pada Tabel 7.

Pengujian pertama dilakukan untuk menguji hipotesis pertama yang menyatakan bahwa CSR berpengaruh terhadap Nilai perusahaan. Hasil pengujian ini menunjukkan nilai probabilitas sebesar 0,050 yang menunjukkan bahwa hubungan kedua variabel berpengaruh, dengan nilai $t$ yaitu $-1,98$ dimana nilai tersebut lebih besar dari 0,05 menunjukkan pengaruh negatif, sehingga dapat di simpulkan bahwa CSR berpengaruh negatif terhadap Nilai Perusahaan. Hasil penelitin ini sejalan dengan penelitian Chen dan Lee (2017) CSR ditemukan memiliki pengaruh negatif yang signifikan terhadap nilai perusahaan dengan sampel penelitian menggunakan perusahaan Taiwan yang terdaftar dari 2010 hingga 2012.

Pengujian kedua dilakukan untuk menguji hipotesis kedua yang menyatakan bahwa CSR berpengaruh terhadap Reputasi perusahaan. nilai probabilitas sebesar 0,003 dimana nilai tersebut tidak lebih dari 0,05 yang menunjukkan bahwa hubungan kedua variabel berpengaruh, dengan nilai $t$ yaitu 3,00 yang menunjukkan bahwa CSR terhadap reputasi perusahaan berpengaruh positif. Hasil Penelitian ini sejalan dengan penelitian yang dilakukan oleh Ali (2011) bahwa pengaruh CSR terhadap Reputasi perusa-haan berpengaruh positif.

Pengujian ke tiga dilakukan untuk menguji hipotesis ketiga yang menyatakan bahwa Reputasi perusahaan berpengaruh terhadap Nilai Perusahaan. Hasil pengujian ini menunjukkan nilai probabilitas sebesar 0,013 dimana nilai tersebut tidak lebih dari 0,05 yang menunjukkan bahwa hubungan kedua variabel berpengaruh, dengan nilai $t$ yaitu 2,53 yang menunjukkan bahwa Reputasi perusahaan berpengaruh positif terhadap Nilai perusahaan. 
Tabel 7

Sobel Test

\begin{tabular}{ccccc}
\hline Independet & Mediating & Dependent & t-Statistik & P- Value \\
\hline \hline CSR & Reputasi Perusahaan & Nilai Perusahaan & 1.93 & 0.053 \\
\hline Sumber: Data Sekunder yang diolah & & &
\end{tabular}

Hasil penelitian ini sejalan dengan penelitian yang di temukan oleh Ramos et al. (2018) yang menyatakan bahwa reputasi yang kuat dapat meningkatkan keuangan perusahaan yang mana tentunya juga akan berdampak pada nilai perusahaan yang lebih baik, tidak hanya itu reputasi yang baik juga memberkuat hubungan perusahaan dengan pemangku keperntingan (Fombrun et al., 2015).

Peneliti juga menguji terkait pengaruh CSR terhadap Nilai perusahaan yang di mediasi oleh Reputasi Perusahaan dimana hasil penelitian ini menunjukkan bahwa CSR berpengaruh terhadap Nilai perusahaan dan hampir di mediasi oleh Reputasi perusahaan sesuai dengan hasil pada tabel 6 akan tetapi jika dilihat dari nilai $\mathrm{t}$ statistik pada tabel 7 adalah 1,93 dengan signya 0,053 menandakan bahwa CSR terhadap Nilai perusahaan hampir di mediasi oleh Reputasi perusahaan dimana nilai $t$ statistic harus lebih dari 1,96 sehingga bisa di katakan dapat di mediasi oleh reputasi perusahaan.

\section{Pembahasan}

\section{CSR Berpengaruh Negatif Terhadap Nilai Perusahaan}

Peneliti melakukan uji hipotesis mengenai pengaruh variabel corporate social responcibility dan reputasi perusahaan terhadap nilai perusahaan. Dikarenakan dengan dikeluarkannya UU No. 40 tahun 2007 tentang Perseroan Terbatan pasal 74, dimana perusahaan erat kaitannya dengan lingkungan dan sumberdaya alam, sehingga mewajibkan perusahaan dalam bertanggung jawab terhadap aspek sosial dan lingkungan, akan tetapi masih banyaknya perusahaan yang enggan dan mengabaikan hal tersebut, dibuktikan dengan banyakanya kerusakan lingkungan,seperti penebangan pohon dan pembuangan limbah yang tidak sesuai de- ngan aturan sehingga berdampak negatif terhadap masyarakat sekitar perusahaan. Padahal dengan perusahaan dapat berkontribusi melakukan kewajibannya untuk ikut serta dalam kegiatan CSR, tentu hal tersebut berdampak terhadap dan nilai perusahaan serta jika reputasi perusahaan kinerjanya dapat di katakana baik, juga akan meningkatkan nilai dari suatu perusahaan tersebut.

Berdasarkan hasil uji hipotesis pertama hasil output dari stata 15 menunjukkan bahwa corporate social responcibility (CSR) berpengaruh negatif terhadap nilai perusahaan Hasil penelitian ini menunjukkan bahwa besar kecilnya praktik corporate social responcibility mempengaruhi nilai perusahaan, akan tetapi dalam penelitian ini CSR berpengaruh negatif terhadap nilai perusahaan, yang menunjukkan bahwa perusahaan yang mengungkapkan CSR berdampak negatif terhadap nilai perusahaannya, penelitian ini sejalan dengan penelitian Becchetti et al. (2012) menunjukkan bahwa berinvestasi dalam CSR dapat meningkatkan biaya dan menyebabkan penurunan kinerja operasional, melemahkan daya saing dan oleh karena itu berdampak negatif pada nilai perusahaan, Bragdon dan Marlin (1972) menunjukkan bahwa peningkatan biaya investasi dalam CSR menempatkan perusahaan pada posisi yang kurang menguntungkan dalam pasar yang kompetitif, dan melemahkan kinerja keuangan. Handerson (2001) dalam Rajput et al. (2012) juga menunjukkan bahwa respon publik terhadap CSR perusahaan terbatas dan tidak membangun nilai perusahaan karena keuntungan reputasi membutuhkan waktu yang lama untuk dikembangkan. Hasil penelitian menunjukkan bahwa pada awalnya, perusahaan harus mengeluarkan biaya peluang untuk mengalokasikan dana untuk kegiatan CSR tanpa mengalami manfaat yang signifikan. 
Masyarakat memandang pemenuhan CSR sebagai kewajiban dasar korporasi. Oleh karena itu, sebelum transisi, CSR memiliki dampak negatif yang signifikan terhadap nilai perusahaan, karena biaya lebih besar daripada keuntungan di awal. Namun, akan ada saatnya pemegang kepentingan juga mulai merasakan manfaat dampak dari terlibatnya perusahaan dalam kegiatan CSR dan mulai memperhatikan investasi dalam CSR yang di lakukan perusahaan, yang secara tidak langsung meningkatkan reputasi bisnis dan kinerja operasional. Manfaat marjinal secara bertahap melebihi biaya marjinal, yang pada akhirnya juga meningkatkan nilai perusahaan sesuai dengan stakeholder theory.

\section{CSR Berpengaruh Positif Terhadap Reputasi Perusahaan}

Hasil penelitian dari hipotesisi kedua menunjukkan bahwa ada hubungan positif antara CSR dan reputasi perusahaan sesuai dengan pengajuan hipotesis pada penelitian ini, Korporasi menjalankan tanggung jawab sosial yang lebih luas termasuk bagian dari etika bisnis, praktik perburuhan, dan tanggung jawab kepada masyarakat luas dan mengurangi kerusakan lingkungan dari produksi massal serta tindakan sosial lainnya yang mereka yakini saat membentuk citra perusahaan di masyarakat. Dengan berjalannya waktu, harapan masyarakat terhadap perusahaan telah meningkatkan kesejahteraan masyarakat. Secara global, stakeholder menganggap perusahaan bertanggung jawab atas perlindungan dalam aspek sosial dan lingkungan. Semakin banyak perusahaan yang menggunakan sumber daya keuangan yang besar untuk mengembangkan citra perbuatan baik guna memperkuat hubungannya dengan semua pemangku kepentingan terutama pelanggan, karyawan, investor, pemerintah, dan masyarakat. Citra perusahaan yang berkinerja baik juga berkembang membangun reputasi perusahaan yang baik. Korporasi memanfaatkan reputasi pasar yang baik dengan berbagai cara. Terlebih lagi, ekonomi kompetitif saat ini menjadi sangat sulit bagi perusahaan untuk memastikan pertumbuhan yang berkelanjutan. Kinerja sosial perusahaan dan reputasi perusahaan yang baik membantu organisasi mencapai pertumbuhan yang berkelanjutan di pasar dengan menarik dan mempertahankan pelanggan, karyawan, dan investor. Penelitian ini sejalan dengan penelitian yang di lakukan oleh Yadav et al. (2018) mengungkapkan CSR berpengaruh terhadap reputasi perusahaan .

\section{Reputasi Perusahaan Berpengaruh Positif Terhadap Nilai perusahaan}

Hasil penelitian tentang pengaruh reputasi perusahaan terhadap nilai perusahaan menunjukkan bahwa reputasi perusahaan berpengaruh positif terhadap nilai perusahaan sejalan dengan pengajuan hipotesis ke tiga pada penelitian ini. Dengan Reputasi perusahaan yang baik dapat membantu perusahaan untuk mendapatkan sumber daya dan dukungan dari para pemangku kepentingan, sesuai dengan teori stakeholder, dengan hal ini menciptakan reputasi yang baik di mata para pemangku kepentingan merupakan hal pengting yang harus di lakukan perusahaan sehingga membantu perusahaan untuk memberikan apa yang menjadi kebutuhan pemangku kepentingan dengan reputasi perusahaan yang baik. Reputasi perusahaan yang baik dapat mempengaruhi kepuasan pelanggan dan karyawan perusahaan, meningkatkan loyali-tas pelanggan dan meningkatkan kelang-sungan hidup perusahaan dalam jangka panjang dan tentunya nilai perusahaan juga akan meningkat. Penelitian ini sejalan dengan penelitian Helm (2007) mengemuka-kan bahwa reputasi yang baik meningkatkan kepuasan investor dan loyalitas afektif terhadap suatu perusahaan yang nantinya dapat meningkatkan nilai perusahaan, serta tidak sejalan dengan penelitian yang dilakukan oleh Daromes (2020) dengan hasil penelitiannya yang menyatakan bahwa Pengujian statistik secara positif memper-kirakan bahwa 
reputasi perusahaan mem-pengaruhi nilai perusahaan.

\section{Pengaruh CSR Terhadap Nilai Perusahaan} yang di Mediasi oleh Reputasi Perusahaan

Makna yang dapat diambil dari pengujian di atas dari pengungkapan CSR terhadap nilai perusahaan hampir di mediasi oleh reputasi perusahaan dalam penelitian ini, artinya pengungkapan CSR yang dilakukan oleh perusahaan di barengi dengan reputasi perusahaan yang baik belum mampu mempengaruhi nilai perusahaan. Hal ini menunjukkan stakeholders perusahaan manufaktur di Indonesia belum melihat pengungkapan CSR dari perusahaan sebagai dasar dalam menentukan nilai dari perusahaan tersebut meskipun perusahaan tersebut memiliki reputasi yang baik. Dengan kata lain, selain membangun reputasi, diperlukan mekanisme lain untuk mendukung pembentukan nilai perusahaan. Stakeholders lebih melihat reputasi perusahaan dibandingkan dengan pengungkapan CSR nya.

\section{SIMPULAN DAN SARAN Simpulan}

Penelitian ini secara empiris mengkaji pengaruh antara CSR dan reputasi perusahaan terhadap nilai perusahaan. Berdasarkan analisis data yang telah dilakukan sebelumnya maka dapat diambil kesimpulan dari penelitian ini yaitu CSR berpengaruh negatif terhadap nilai perusahaan. Penelitian ini menunjukkan bahwa semakin tinggi tingkat pengungkapan CSR maka nilai perusahaan akan semakin menurun, karena di duga perusahaan akan mengeluarkan pengeluaran secara lebih dalam kegiatan CSR, yang mana manfaatnya dapat di rasakan di masa mendatang. Sebaliknya, reputasi perusahaan berpengaruh positif terhadap nilai perusahaan. Hasil lain menegaskan bahwa reputasi perusahaan berperan dalam hampir memediasi pengaruh CSR pada nilai perusahaan. Implikasi teoritis dari penelitian ini berkontribusi pada teori stakeholder yang dikemukakan oleh Freeman, (1984), Donaldson dan Preston,
(1995) (dalam Ghozali, 2020) yang menyatakan bahwa perusahaan yang dapat membuat stakeholdernya lebih baik, maka perusahaan ini akan mendapatkan dukungan dari stakeholder demi kelancaran kegiatan perusahaan dalam beroperasi. Kegiatan CSR yang dilakukan oleh perusahaan akan menjadi wujud kepedulian perusahaan terhadap sosial dan lingkungan. Dengan demikian, perusahaan akan terhindar dari risiko pemadaman bisnis atau keterbatasan sumber daya dan dapat meningkatkan nilai perusahaan. Hasil penelitian ini juga memperkuat penelitian yang dikemukakan oleh Gray et al., (1995) dalam Farook et al. (2011) yang menyatakan bahwa tanggung jawab sosial perusahaan bermanfaat untuk meningkatkan reputasi perusahaan, menjaga citra dan strategi perusahaan.

Kegiatan CSR yang dapat digunakan untuk menjaga legitimasi masyarakat dan akan menciptakan hubungan yang harmonis. Dengan hubungan yang harmonis, perusahaan akan menciptakan reputasi yang baik di mata para pemangku kepentingan. Reputasi ini akan hamper memperkuat pengaruh CSR terhadap peningkatan nilai perusahaan. Penelitian ini diharapkan dapat bermanfaat bagi perusahaan, membantu perusahaan untuk mengetahui cara-cara yang lebih baik dalam meningkatkan nilai perusahaan dan memberikan pemahaman tentang pentingnya tanggung jawab sosial dan lingkungan yang tidak hanya terfokus pada kepentingan ekonomi. Melalui kegiatan CSR, perusahaan akan mendapatkan keuntungan jangka panjang dari perusahaan yang berkelanjutan, dan reputasi perusahaan yang baik.

\section{Saran}

Perusahaan yang melakukan kegiatan CSR akan memberikan jaminan keamanan yang lebih besar kepada investor dalam berinvestasi karena perusahaan yang memiliki tanggung jawab sosial dan lingkungan yang tinggi akan memiliki jaminan kelangsungan hidup yang tinggi pula. Penelitian ini memiliki beberapa keterbatasan yang perlu diperhatikan bagi peneliti selanjutnya untuk 
dapat mengembangkan penelitian ini, pengukuran CSR hanya bersumber dari laporan tahunan perusahaan dalam 1 periode, dan masih banyak perusahaan yang belum mengungkapkan kegitaan CSR yang di lakukan oleh perusahaan. Selain itu dalam penelitian ini reputasi perusahaan hanya diproxikan dari 100 excellent growth company ranks 2018 pada media bisnis Indonesia. Untuk menjawab keterbatasan penelitian ini, penelitian selanjutnya perlu memperhatikan hal-hal tersebut dan dapat menambah jumlah sampel penelitian atau meneliti pada sektor industry yang lainnya atau menggunakan proxy lain dalam mengukur reputasi perusahaan.

\section{DAFTAR PUSTAKA}

Ali, I. 2011. Influence of Corporate Social Responsibility on Development of Corporate Reputation and Customer Purchase Intentions. Munich Personal RePEc Archive (MPRA) Paper No. 33889.

Alvesson, M. 1990. Organization: from Substance to Image? Organization Studies 11(3): 373-394.

Anggraeni, D. Y. dan C. D. Djakman. 2018. Pengujian terhadap Kualitas Pengungkapan CSR di Indonesia. EKUITAS (Jurnal Ekonomi dan Keuangan) 2(1): 2241.

Arikan, E., D. Kantur, C. Maden, dan E.-E. Telci. 2016. Investigating the Mediating Role of Corporate Reputation on the Relationship between Corporate Social Responsibility and Multiple Stakeholder Outcomes. Quality \& Quantity 50(1): 129149.

Becchetti, L., R. Ciciretti, I. Hasan, dan N. Kobeissi. 2012. Corporate Social Responsibility and Shareholder's Value. Journal of Business Research 65(11): 1628-1635.

Bidhari, S. C., U. Salim, S. Aisjah, dan E. Java. 2013. Effect of Corporate Social Responsibility Information Disclosure on Financial Performance and Firm Value in Banking Industry Listed at Indonesia Stock Exchange. European Journal of Business and Management 5(18): 39-46.
Boddy, C. 2012. The Impact of Corporate Psychopaths on Corporate Reputation and Marketing. The Marketing Review 12(1): 79-89.

Bragdon, J. H. dan J. Marlin. 1972. Is Pollution Profitable. Risk Management 19(4): 9-18.

Brigham, E. F. dan J. F. Houston. 2013. Dasardasar Manajemen Keuangan (11 ed.). Salemba Empat. Jakarta.

Chalençon, L., A. Colovic, O. Lamotte, dan U. Mayrhofer. 2017. Reputation, eReputation, and Value-Creation of Mergers and Acquisitions. International Studies of Management $\mathcal{E}$ Organization 47(1): 4-22.

Chen, R. C. dan C.-H. Lee. 2017. The Influence of CSR on Firm Value: an Application of Panel Smooth Transition Regression on Taiwan. Applied Economics 49(34): 3422-3434.

Daromes, F. E. 2020. Joint Impact of Philanthropy and Corporate Reputation on Firm Value. Jurnal Dinamika Akuntansi 12(1): 1-13.

Deegan, C. 1. 2002. The Legitimising Effect of Social and Environmental Disclosures A Theoretical Foundation. Accounting, Auditing Accountability Journal 15(3): 282311.

Deephouse, D. L. 2000. Media Reputation as a Strategic Resource: an Integration of Mass Communication and ResourceBased Theories. Journal of Management 26(6): 1091-1112.

Dierickx, I. dan K. Cool. 1989. Asset Stock Accumulation and Sustainability of Competitive Advantage. Management Science 35(12): 1504-1511.

Epstein, M. J. dan M. Freedman. 1994. Social Disclosure and the Individual Investor. Accounting, Auditing Accountability Journal 7(4): 94-109.

Farook, S., M. K. Hassan, dan R. Lanis. 2011. Determinants of Corporate Social Responsibility Disclosure: the Case of Islamic Banks. Journal of Islamic Accounting and Business Research 2(2): 114-141. 
Fombrun, C. J., L. J. Ponzi, dan W. Newburry. 2015. Stakeholder Tracking and Analysis: The RepTrak® System for Measuring Corporate Reputation. Corporate Reputation Review 18(1): 3-24.

Foote, J., N. Gaffney, dan J. R. Evans. 2010. Corporate Social Responsibility: Implications for Performance Excellence. Total Quality Management 21(8): 799-812.

Friedman, R. 1984. Strategic Management: a Stakeholder Perspective. Prentice-Hall. Estados Unidos.

Gamerschlag, R., K. Möller, dan F. Verbeeten. 2011. Determinants of Voluntary CSR Disclosure: Empirical Evidence from Germany. Review of Managerial Science 5(2-3): 233-262.

Geller, G. 2014. A Review and Critique on the Relation between Corporate Reputation, Value Creation and Firm Performance. Amazônia, Organizações e Sustentabilidade 3(1).

Ghahroud, M. L., S. Hosseini, A. Ariannejad, dan E. Partovi. 2020. The Impact of Corporate Social Responsibility (CSR) on Bank Reputation and Financial Performance (Case Study: Iranian Banks). Journal of Economics and Environment $1(1)$.

Ghozali, I. 2020. 25 Grand Theory 25 Teori Besar Ilmu Manajemen, Akuntansi, dan Bisnis. Yoga Pratama. Semarang.

Gilbert, Jr. D. R. 2005. Corporate Strategy and Ethics, as Corporate Strategy Comes of Age. The Blackwell Handbook of Strategic Management: 564-584.

Gras-Gil, E., M. P. Manzano, dan J. H. Fernández. 2016. Investigating the Relationship between Corporate Social Responsibility and Earnings Management: Evidence from Spain. BRQ Business Research Quarterly 19(4): 289-299.

Helm, S. 2007. The Role of Corporate Reputation in Determining Investor Satisfaction and Loyalty. Corporate Reputation Review 10(1): 22-37.

Irawan, D., E. Bastian, dan I. A. Hanifah. 2019. Knowledge Sharing, Organizational Culture, Intellectual Capital, and
Organizational Performance. Journal of Accounting and Investment 20(3): 267-282. Jackson, E. A. dan H. F. Jackson. 2017. The Role of Corporate Social Responsibility in Improving Firms' Business in the Directions of Sustainable Development, Accountability and Transparency. African Journal of Economic and Sustainable Development 6(2-3): 105-118.

Jo, H. dan M. A. Harjoto. 2011. Corporate Governance and Firm Value: The Impact of Corporate Social Responsibility. Journal of Business Ethics 103(3): 351-383.

Jukić, D., T. Stantić, dan R. Jozipović-Sudar. 2018. Analysis of Building a Corporate Brand in Construction. Young Economists Journal/Revista Tinerilor Economisti 15(31).

KadłubeNa, M. 2015. The Essence of Corporate Social Responsibility and the Performance of Selected Company. Procedia-Social Behavioral Sciences 213: 509-515.

Karaye, Y. I., Z. Ishak, dan N. Che-Adam. 2014. The Mediating Effect of Stakeholder Influence Capacity on the Relationship between Corporate Social Responsibility and Corporate Financial Performance. Procedia-Social and Behavioral Sciences 164: 528-534.

Kelley, K. J., T. A. Hemphill, dan Y. Thams. 2019. Corporate Social Responsibility, Country Reputation and Corporate Reputation. Multinational Business Review 27(2): 178-197.

Knight, R. F. dan D. J. Pretty. 1999. Corporate Catastrophes, Stock Returns, and Trading Volume. Corporate Reputation Review 2(4): 363-378.

Lanis, R. dan G. Richardson. 2012. Corporate Social Responsibility and Tax Aggressiveness: an Empirical Analysis. Journal of Accounting Public Policy 31(1): 86-108.

Lee, D., S. Lee, dan N. E. Cho. 2019. Voluntary Disclosure and Market Valuation of Sustainability Reports in Korea: The Case of Chaebols. Sustainability 11(13): 3577. 
Logsdon, J. M. dan D. J. Wood. 2002. Reputation as an Emerging Construct in the Business and Society Field: an Introduction. Business Society 41(4): 365370.

Mahrani, M. dan N. Soewarno. 2018. The Effect of Good Corporate Governance Mechanism and Corporate Social Responsibility on Financial Performance with Earnings Management as Mediating Variable. Asian Journal of Accounting Research 3(1): 41-60.

Palmer, H. J. 2012. Corporate Social Responsibility and Financial Performance: Does it Pay to be Good? CMC Senior Theses, Paper 529.

Parket, I. R. dan H. Eilbirt. 1975. The Practice of Business Social Responsibility: The Underlying Factors. Business Horizons 18(4): 5-10.

Petkova, A. P. 2016. Standing Out or Blending in? The Formation of New Firms' Legitimacy and Reputation under Different Levels of Market Uncertainty. Corporate Reputation Review 19(1): 22-34.

Rajput, N., G. Batra, dan R. Pathak. 2012. Linking CSR and Financial Performance: an Empirical Validation. Problems and Perspectives in Management 10(2): 42-49.

Ramos, M. I. G., M. J. D. Manzanares, dan F. G. Gómez. 2018. The Effect of Technological Posture and Corporate Social Responsibility on Financial Performance through Corporate Reputation. International Journal of Innovation: IJI Journal 6(2): 164-179.

Roberts, P. W. dan G. R. Dowling. 2002. Corporate Reputation and Sustained Superior Financial Performance. Strategic Management Journal 23(12): 1077-1093.

Rose, C. dan S. Thomsen. 2004. The Impact of Corporate Reputation on Performance:: Some Danish Evidence. European Management Journal 22(2): 201-210.

Roszkowska-Menkes, M. T. 2018. Integrating Strategic CSR and Open Innovation. Towards a Conceptual Framework. Social Responsibility Journal 14(4): 950-966.
Siregar, C. N. 2007. Analisis Sosiologis terhadap Implementasi Corporate Social Responsibility pada Masyarakat Indonesia. Jurnal Sosioteknologi 6(12): 285-288.

Statman, M., K. L. Fisher, dan D. Anginer. 2008. Affect in a Behavioral AssetPricing Model. Financial Analysts Journal 64(2): 20-29.

Topalian, A. 1984. Corporate Identity: Beyond the Visual Overstatements. International Journal of Advertising 3(1): 55-62.

Ulum, I. dan A. Juanda. 2018. Metode Penelitian Akuntansi. Edisi 2. Aditya Media Publishing. Yogyakarta.

Vélaz, I., A. J. G. Sison, dan J. Fontrodona. 2007. Incorporating CSR and Stakeholder Management into Corporate Strategy: a Case Study of the CAN Experience 2002-2006. Corporate Governance: The International Journal of Business in Society 7(4): 434-445.

Walker, K. 2010. A Systematic Review of the Corporate Reputation Literature: Definition, Measurement, and Theory. Corporate Reputation Review 12(4): 357-387.

Wang, R. 2012. Socially Responsible Supply Chain Partnership Based on CSR Equity Model. American Journal of Industrial Business Management 2(04): 184-193.

Wei, J., Z. Ouyang, dan H. Chen. 2017. Well Known or Well Liked? The Effects of Corporate Reputation on Firm Value at the Onset of a Corporate Crisis. Strategic Management Journal 38(10): 2103-2120.

Weigelt, K. dan C. Camerer. 1988. Reputation and Corporate Strategy: a Review of Recent Theory and Applications. Strategic Management Journal 9(5): 443-454.

Wicaksono, A. P. N. 2020. Apakah Reputasi Perusahaan Menghasilkan Laba yang Berkualitas di Indonesia? Journal of Applied Accounting \& Taxation 5(1): 95100.

Yadav, R. S., S. S. Dash, S. Chakraborty, dan M. Kumar. 2018. Perceived CSR and Corporate Reputation: the Mediating 
364 Ekuitas: Jurnal Ekonomi dan Keuangan - Volume 5, Nomor 3, September 2021 : 346 - 364

Role of Employee Trust. Vikalpa 43(3): 139-151.

Yaldo, I., H. Dong, G. Woodbine, dan Y. Fan. 2014. An ontological model for corporate social responsibility (CSR) reporting based on global reporting initiative GRI G4. Proceedings of the 25th Australian Conference on Information Systems.
Yoon, Y., Z. Gürhan-Canli, dan N. Schwarz. 2006. The Effect of Corporate Social Responsibility (CSR) Activities on Companies with Bad Reputations. Journal of Consumer Psychology 16(4): 377-390. 